\title{
Proizvodnja duhana u Republici Hrvatskoj
}

\section{Sažetak}

Duhanu su se pripisivala mnoga svojstva, od toga da je "sveta biljka", do toga da nije dobar za konzumaciju. Bez obzira na to, duhan ima tradiciju uzgoja otkako je otkriven Novi svijet. Obično se proizvodnja duhana povezuje s gospodarstvima država. I Republika Hrvatska ima višestoljetnu tradiciju uzgoja duhana. No, slabim subvencioniranjem uzgoja duhana proizvodnja stagnira, odnosno u blagom je padu; dok prirod raste.

Ključne riječi: duhan, svijet, EU, zakon o duhanu, Republika Hrvatska

\section{Uvod}

Po francuskom je ambasadoru Jeanu Nicotu nazvan rod Nicotiana te glavni sastojak duhana - nikotin (Goodman, 2005). Duhan (Slika 1) kakav se danas poznaje i koristi, samo je jedna od vrsta biljke Nicotiana, a alkaloid nikotin biljka duhana proizvodi u korijenu, odlaže ga u listovima te ima psihoaktivan i stimulirajući utjecaj na ljudsko tijelo (Goodman, 1993). Sadržaj nikotina povećava se zrelošću duhana u osušenim listovima (Čavlek i Gršić, 2008, Taylor i sur., 2011). Lišće duhana poslije sušenja, sortiranja i fermentacije služi kao osnovna sirovina za izradu cigara i drugih sličnih sredstava. Duhanu su se pripisivala pozitivna svojstva za koja se tvrdilo da pomažu očuvati zdravlje (Gately, 2001). Nažalost, trebalo je dugo vremena da znanstvena zajednica shvati da uporaba duhana izaziva ovisnost (Kourakos i sur., 2017). S ciljem smanjenja broja konzumenata, krajem 16. stoljeća stvoreni su temelji oporezivanja duhana u Engleskoj te takva politika oporezivanja postoji još i danas (Goodman, 2005). Prvi spomen na duhan u okvirima današnje Republike Hrvatske (RH) seže u Dubrovačku Republiku, kada se spominje uvoz duhana iz Ancone 1632. godine. Potom se duhan spominje u odluci Senata Dubrovačke Republike iz 1648. godine kojom se uvodi ili povećava carina na uvoz duhana u Dubrovačku Republiku (Čagalj i sur., 2017). U Dalmaciji se duhan uzgajao u manjim količinama za vrijeme mletačke uprave u 17. stoljeću kada je Venecija 1665. godine davala pravo proizvodnje duhana u zakup (Vrzan, 2017). Na drugoj strani Hrvatske, uzgoj duhana na području Baranje, Požege i Virovitice započinje oslobođenjem Slavonije od Osmanlija (oko 1690. god.), a za nju su bili zaduženi isusovci (Bauk, 2015; Dundović, 2019). U Vojnoj krajini graničari su mogli saditi duhan bez plaćanja poreza, ali samo ako visina uroda nije prelazila količinu dovoljnu za vlastitu uporabu (Vrzan, 2017). Za vrijeme Habsburške Monarhije, car Josip II. uveo je državni monopol na duhan čime je 1784. godine država preuzela kontrolu nad proizvodnjom, preradom i prodajom duhana (Bauk, 2015). Kada je Dalmacija 1797. godine pripala Habsburškoj Monarhiji, taj se monopol primjenjivao i na nju, dok je proizvodnja duhana bila dopuštena jedino u knežiji Poljica (Vrzan, 2017). Također, u Grbi kraj Nina je krajem 18. stoljeća utemeljena manufaktura i skladište duhana o čijem je poslovanju u Veneciji izdana knjižica na 39 stranica. Mletačka Republika je u Zadru osnovala manufakturu za izradu vreća u koje se pakirao duhan proizveden kraj Nina (Bauk, 2015). Krajem 19. stoljeća potrošnja duhana bila je na vrhuncu pa se samim time pove- 
ćao i uzgoj. Došlo je do izgradnje duhanskih stanica u Imotskom, Vrgorcu, Dubrovniku, Sinju, Metkoviću i Splitu, a nešto kasnije u Trogiru i Drnišu. U tim je stanicama zapošljavano stručno osoblje za uzgoj duhana, dok su žene i djeca razvrstavali otkupljeni duhan (Vrzan, 2017). Proizvodnja duhana u Istri počinje tek 1923. godine u formi zadruga na području koje omeđuje Poreč, Pazin i Pulu (Bauk, 2015). Uvođenjem radničkog samoupravljanja 1951. godine, osnivaju se poduzeća za otkup i obradu duhana. Od 1954. godine, slavonski i podravski uzgajivači u suradnji sa stručnjacima zagrebačkog Duhanskog instituta počinju saditi dvije nove vrste, burley i svijetla virginia, za koje se pokazalo da im odgovara pjeskovito tlo tog područja (Vrzan, 2017). Epidemija plamenjače, koja je devastirala duhaništa u Dalmaciji i Hercegovini, rezultirala je 1960. i 1962. godine značajnim padom proizvodnje te zatvarenjem duhanskih stanica u Sinju i Drnišu. Duhanska industrija u Dalmaciji je tijekom 1970-ih postupno odumirala (Bauk, 2015).

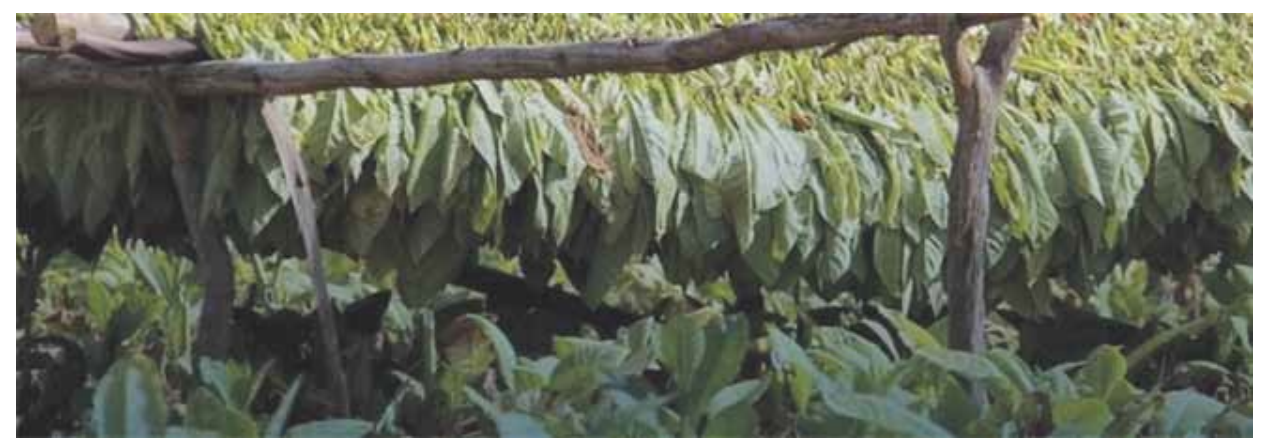

Slika 1. Listovi duhana

Figure 1. Tobacco leaves

Izvor/Source: https://poljoprivreda.gov.hr/duhan-i-konoplja/198

\section{Uzgoj duhana u Republici Hrvatskoj}

Prema Stipetiću (2005), od 1900.-1904. godine u RH proizvodilo se godišnje oko $1800 \mathrm{t}$ duhana. Uspoređujući potonje sa proizvodnjom u novom tisućljeću, može se primijetiti kako je proizvodnja u 2004. godini (Tablica 1) oko 6 puta veća od one prije 100 godina, što potvrđuje tezu da je uzgoj duhana u $\mathrm{RH}$ evoluirao u tom razdoblju.

Tablica 1. Zasađeno i proizvedeno duhana u Hrvatskoj (2000.-2004. godina)

Table 1. Tobacco planted and produced in Croatia (2000.-2004. year)

\begin{tabular}{cccccc}
\hline Duhan/Tobacco & 2000. & 2001. & 2002. & 2003. & 2004. \\
\hline Površina/Area (ha) & 5.678 & 5.500 & 5.489 & 5.748 & 5.394 \\
\hline Proizvodnja/Production (t) & 9.714 & 10.502 & 10.905 & 9.680 & 10.293 \\
\hline Prirod/Yield (t ha-1) & 1,7 & 1,9 & 2,0 & 1,7 & 1,9 \\
\hline
\end{tabular}

Izvor/Source: Državni zavod za statistiku, 2018. PC-Axix baze podataka

Nažalost, od 2004. godine, pa u sljedećem desetljeću i pol, proizvodnja se smanjila za oko četvrtinu (Tablica 2). Promatrajući isto razdoblje, smanjila se i površina za nešto više od četvrtinu $(28 \%)$, dok je prirod neznatno rastao. 
Tablica 2. Zasađeno i proizvedeno duhana u RH (2014.-2018. godina)

Table 2. Tobacco planted and produced in Croatia (2014.-2018. year)

\begin{tabular}{cccccc}
\hline Duhan/Tobacco & 2014. & 2015. & 2016. & 2017. & 2018. \\
\hline Površina/Area (ha) & 5.196 & 4.752 & 4.413 & 4.563 & 3.834 \\
\hline Proizvodnja/Production (t) & 9.164 & 10.132 & 8.977 & 9.413 & 7.561 \\
\hline Prirod/Yield (t ha-1) & 1,8 & 2,1 & 2,0 & 2,1 & 2,0 \\
\hline
\end{tabular}

Izvor/Source: Državni zavod za statistiku, 2018. PC-Axix baze podataka

Rast priroda može se pripisati obiteljskim poljoprivrednim gospodarstvima koja su počela navodnjavati proizvodne površine. Na takvim površinama prirodi se penju i na 3,5 t ha-1, na posjedima veličine 5-10 ha (27,4 \%), ili većim gospodarstvima $10-20$ ha $(21,5 \%$ od ukupnog broja). Od 2015. godine u okviru sustava izravnih plaćanja, sektor duhana nije uključen u prihvatljive sektore za proizvodno vezana plaćanja. U strukturi vrijednosti otkupa i prodaje poljoprivrednih proizvoda u 2018. godini neprerađeni je duhan imao učešće s 1,3 \% (Tablica 3).

Tablica 3. Otkup i prodaja poljoprivrednih proizvoda u Hrvatskoj, od 2014. do 2018. godine

Table 3. Purchase and sale of agricultural products in Croatia, from 2014. to 2018. year

\begin{tabular}{lccccc}
\hline & 2014. & 2015. & 2016. & 2017. & 2018. \\
\hline $\begin{array}{l}\text { Ukupno/Total (milijuni kn/millions of HRK) } \\
\begin{array}{l}\text { Neprerađeni duhan/Unprocessed tobacco } \\
\text { (milijuni kn/millions of HRK) }\end{array}\end{array}$ & 7138,5 & 6732,2 & 7057,4 & 7370,4 & 7349,4 \\
\hline
\end{tabular}

Izvor/Source: Godišnje izvješće o stanju poljoprivrede u 2018. godini

U 2018. godini potrošačke cijene duhana porasle su za 3,5 \%. Državna potpora za iznimno osjetljive sektore, među kojima je i duhan, od 2017. se godine financira u skladu s pravilima uredbi Europske unije (EU) koje uređuju potpore manje vrijednosti. Plaćanja za duhan tipa burley vrši se u skladu Uredbe Komisije (EU) 1408/2013, a plaćanja za duhan tipa viržinija u skladu Uredbe Komisije (EU) 1407/2013. Za financiranje Programa izravnih plaćanja za proizvodnu 2018. godinu, bilo je u Državnom proračunu RH osigurano ukupno 2.712.965.026 kn. Dodatno je još za proizvodnu 2018. godinu isplaćeno 121,3 milijuna kn za iznimno osjetljive sektore, od čega za duhan 37.601.119 kn (Godišnje izvješće o stanju poljoprivrede u 2018. godini). Broj zaposlenih u duhanskoj industriji u 2018. godini, promatrano u odnosu na 2017. godinu, povećan je za $17,8 \%$. Prosječna isplaćena neto plaća po zaposlenome u djelatnostima proizvodnje duhanskih proizvoda u 2018. godini iznosila je 7.861 kn i u usporedbi s prosječnom neto plaćom RH bila je veća za 25,9 \% (Godišnje izvješće o stanju poljoprivrede u 2018. godini). U proizvodnji, najzastupljenija sorta duhana je virginia s oko $90 \%$ zastupljenosti, a u manjim količinama zastupljen je burley. Bilanca vanjskotrgovinske razmjene neprerađenog duhana za 2018. godinu, promatrano vrijednosno i količinski negativna je. U 2018. godini izvezeno je 7.539 t, a uvezeno 8.424 t neprerađenog duhana. Uspoređujući 2018. godinu s prethodnom godinom, količinski gledano, uvoz kategorije neprerađenog duhana povećan je za 38,0\% te iznosi 40,8 milijuna €, dok je izvoz smanjen za 13,2 \% i iznosi 25,6 milijuna € (Godišnje izvješće o stanju poljoprivrede u 2018. godini). Korisnik plaćanja u iznimno osjetljivim sektorima jest poljoprivrednik koji obavlja poljoprivrednu djelatnost na poljoprivrednom gospodarstvu i upisan 
je u Upisnik poljoprivrednika sukladno članku 121. Zakona o poljoprivredi (NN 30/15). Naime, u proizvodnoj 2019. godini zahtjev udruge Krupan list prema organizatorima proizvodnje bio je da prosječna otkupna cijena treba biti za 2,36 kn kg-1 veća u odnosu na 2018. godinu, temeljem kalkulacije troškova proizvodnje te temeljem usporedbi cijena duhana u Europi i regiji. Hrvatski prerađeni duhan u izvozu postiže cijenu 30-35 kn kg-1, a hrvatskim proizvođačima taj se duhan plati 13-14 kn kg-1, što otvara dovoljno prostora da se proizvođačima u Hrvatskoj poveća cijena za traženi iznos. Objavljeno povećanje cijena od nekoliko lipa po kilogramu za prvu klasu, do najviše 50-ak lipa za treću klasu, rezultira proizvođačima duhana koji su sklopili ugovor s otkupljivačima za povećanje cijene u 2019. godini u prosjeku 14 Ip po svakoj otkupnoj klasi. To iznosi $6 \%$ od traženog povećanja, tako da ukupno povećanje prosječne otkupne cijene u 2019. godini iznosi 1,1\%, a takvo povećanje cijene nije dostatno ni za pokrivanje rasta troškova u 2019. godini, koji iznose prosječno 0,93 kn kg-1. S obzirom na nepovoljne klimatske uvjete te smanjenje površina u 2019. godini, doći će do toga da će proizvodna 2019. godina biti povijesno niska, s volumenom proizvodnje ispod 7 milijuna kg (Agroklub). Stoga su izazovi koji stoje pred proizvođačima duhana u budućnosti veliki, a rješenje se može pronaći u višoj otkupnoj cijeni duhana od otkupljivača, snižavanju troškova proizvodnje te organiziranju proizvođača u proizvođačke organizacije.

\section{Uzgoj duhana u svijetu i EU}

Proizvodnja duhana odvija se u više od 120 zemalja, a u cijelosti se proizvede više od 6 milijuna t god-1 (Grafikon 1).

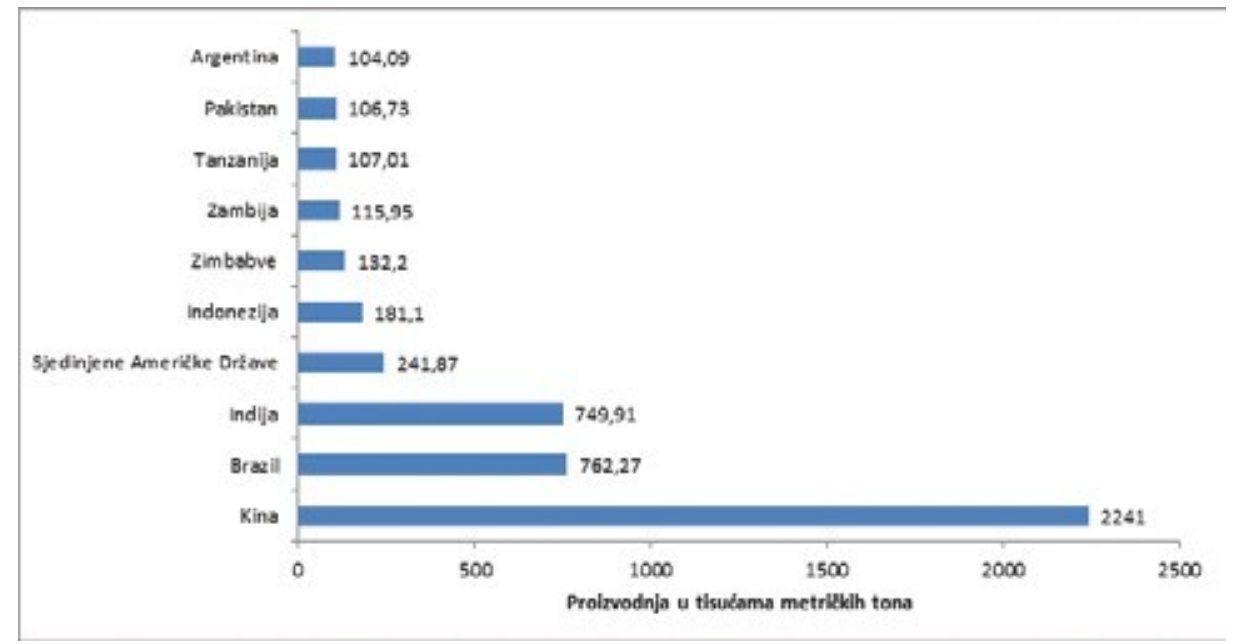

Grafikon 1. Najveći svjetski proizvođači duhana Graph

1. The world's largest tobacco producers Izvor:/Source:

http://www.fao.org/faostat/en/\#data/QC

Kao što se može vidjeti iz Grafikona 1, Kina je najveći proizvođač duhana, a zatim slijedi Brazil, Indija, SAD i Indonezija, kao peti najveći proizvođač. Zimbabve, Zambija, Tanzanija, Pakistan i Argentina sa prethodno nabrojenim državama čine $80 \%$ ukupne svjetske proizvodnje duhana. Također, Kina, Indija, Brazil i Indonezija zauzimaju oko $60 \%$ ukupnih svjetskih površina za uzgoj duhana (Faostat, 2018). Koliko je važno dobro poznavati tehnologiju i agrotehniku proizvodnje duhana, toliko je važno i primijeniti znanje i vještine u svrhu osposobljavanja po- 
ljoprivrednog gospodarstva za postizanje maksimalne dobiti (Kay i sur., 2012). Otkupna cijena duhana u EU, za 2018. godinu, u rasponu je od 2,0 do 3,8€ kg-1 (Dundović, 2019), a prosječna je na razini od 2,5€. Hrvatska ima najmanju otkupnu cijenu u EU s 1,8 € kg-1 duhana (Agroklub). U EU uzgoj duhana se neprestano smanjuje već 30 godina te danas dostiže 140000 t uzgoja u 2018. godini. Iste je godine duhan u EU predstavljao oko 66000 ha (upola manje nego 2001. godine). Duhan se trenutno uzgaja u 12 zemalja EU. Glavni proizvođači su: Italija, Španjolska, Poljska, Grčka, Hrvatska, Francuska, Mađarska i Bugarska, koje čine 99 \% proizvodnje duhana u EU. Postoji trend za manja područja uzgoja, uglavnom zbog pada potrošnje duhanskih proizvoda. Prirodi variraju od 1 do 3 t ha-1, ovisno o sorti. Sorta virginia čini $71 \%$ proizvodnje, burley $16 \%$, orijentalne sorte $7 \%$ a ostale sorte $6 \%$. EU proizvodi manje od $2 \%$ globalne proizvodnje sirovog duhana godišnje. U 2018. godini EU je uvezla oko 420000 t (što ukazuje na trend porasta) i izvezla 120000 t (što ukazuje na trend pada) sirovog duhana. Duhanski režim u EU potpomognut je Uredbom EU 1308/2013 koja definira sirovi duhan. Od 1993. godine u EU se na duhan primjenjuje sustav ograničenja proizvodnje, a od 1. siječnja 2010. godine EU nije dodijelila posebne subvencije za proizvodnju sirovog duhana. Prethodna subvencija za duhan pretvorena je u osnovna plaćanja Uredbom EU 1307/2013 i potporom za ruralni razvoj uredbom EU 1309/2013 (Europska Komisija). Direktiva EU o porezu na duhan kroz svoje minimalne porezne potrebe glavna je pokretačka snaga rasta poreza na cigarete u regiji (Blecher i sur., 2014; Bouw, 2017). Ta povećanja poreza rezultirala su značajnim padom učestalosti pušenja u Europi i služe očuvanju proračunskih prihoda država članica (Gallus i sur., 2006). Ipak, i dalje postoje velike razlike u cijenama cigareta među državama članicama (Lopes i Stoklosa, 2019). Revizija najnižih stopa vraća se na dnevni red Komisije te se sada preispituje, čineći analizu utjecaja cijena cigareta na izbjegavanje poreza i utaju poreza pravodobnom i povezanom (Europska Komisija, 2018). U odredbama Direktive Vijeća 2011/64/EU predviđa se minimalni trošarinski iznos od $90 € / 1000$ cigareta i minimalna trošarina od $60 \%$ ponderirane prosječne maloprodajne cijene (osim ako je trošarina veća od $115 € / 1000$ cigareta) (Vijeće europske unije, 2011). Svjetska zdravstvena organizacija (eng. World Health Organisation - WHO) preporučuje poreznu stopu od najmanje $75 \%$ maloprodajnih cijena cigareta koju postiže 26 država članica EU (World Health Organisation, 2017). Međutim, i dalje su značajne razlike u cijenama između različitih duhanskih proizvoda kao i između zemalja, što pušačima pruža jeftinije alternative i potencijalno slabi utjecaj poreznih politika na zdravlje. Pušenje pokazuje najveći rizik izbjegavanju prerane smrti u EU, odgovoran za 0,7 milijuna smrti svake godine (Thun i sur., 2012). Otprilike polovica pušača umire prerano, što rezultira prosječnim gubitkom od 10 godina života (Doll i sur., 2004). Međutim, i dalje postoji visoka stopa pušenja, a svaki četvrti građanin EU i dalje puši (Special Eurobarometer 458). Povećanje cijena cigareta putem poreza na duhan smatra se jedinom najučinkovitijom intervencijom za smanjenje potražnje za cigaretama (World Health Organisation, 2014). Prema nedavnoj simulacijskoj studiji (Yeh i sur., 2017), prosječno povećanje cijena od $10 \%$ u cijeloj EU dovelo bi do prosječnog povećanja prihoda za 6,8 \%, a prosječna povlastica poreza na duhan u svim zemljama EU povećala bi se za 6,6 milijuna \$. Ono što je najvažnije, takav rast cijena cigareta značajno bi smanjio potrošnju cigareta i broj smrtnih slučajeva uzrokovanih pušenjem (Yehi sur., 2017).

\section{Percepcija duhana u današnje vrijeme}

U današnje vrijeme sa svih strana stižu upozorenja o štetnosti duhana. Istraživanja polovicom 20. stoljeća pokazala su da pušači češće obolijevaju od raka pluća te da nepušači žive duže od pušača. Cigareta, kao najčešći oblik konzumacije duhana, strojnom je proizvodnjom postala dostupnija i jeftinija, a brojne reklame prodavale su duhanske proizvode više nego ikad (Burns, 2007). Nekad je duhan bio „sveta biljka“, korištena u posebnim ritualnim ili pak medicinskim 
svrhama, dok je danas duhan sredstvo koje se svakodnevno konzumira bez razmišljanja, radi navike i osjećaja ugode koju pruža. Prilikom otkrivanja Novog svijeta, puno je mornara usvojilo naviku pušenja, pogotovo onih koji su bili zaraženi sifilisom, a pušenje duhana im je umanjivalo bolove. Također, sir Walter Raleigh je donio duhan na engleski dvor te je on postupno postao sinonim za uživanje, a ubrzo se stvorila i kultura pušenja duhana uz uživanje u alkoholu (Burns, 2007). Prijepori oko duhana sezali su čak i do mišljenja da konzumacija duhana smanjuje požudu (Goodman, 1993). Popularnost duhana proširila se diljem Francuske kada je duhan izliječio jake glavobolje kraljičinog sina (Goodman, 2005). lako je duhanska industrija u svijetu današnjice jedna od najvećih, radi brojnih zakonskih regulativa koje se nameću, susreće se $s$ brojnim preprekama. Motane cigarete dobivaju sve više na popularnosti, posebno u Europi, kao odgovor na porast tvorničkih cijena cigareta i/ili financijski stres zbog globalne ekonomske krize (Chaloupka i sur., 2011; Gallus i sur., 2013). To je potaknuto poreznom razlikom između dvije vrste proizvoda, s tim da se motani duhan oporezuje na nižoj razini, čime je i jeftiniji u većini zemalja (IARC, 2011; Spanopoulos i sur., 2012; Gallus i sur., 2013). Sukladno tome, posljednja direktiva EU o trošarinama na duhan zahtijeva od država članica da imaju minimalni porez od $57 \%$ ponderirane prosječne cijene na tvornički proizvedene cigarete, ili $64 € / 1000$ cigareta; dok je najmanji porez na motane cigarete, $40 \%$ ponderirane prosječne cijene ili $40 €$ kg-1 (Europska komisija, 2010). Duhan ubija najmanje polovicu dugotrajnih pušača, a godišnje rezultira većim brojem smrtnih slučajeva nego HIV/AIDS, tuberkuloza i malarija. Teret bolesti i smrti od duhana postaje sve teži. U 20. stoljeću bilo je oko 100 milijuna smrti od duhana. Ako se postojeći obrasci nastave, duhan će u ovom stoljeću ubiti oko milijardu ljudi, najviše u zemljama s niskim i srednjim dohotkom (Jha i sur., 2017). Zdravstveni sustavi pate i kod pojedinaca. Liječenje brojnih kroničnih bolesti uzrokovanih ili pogoršanih pušenjem, povećava godišnje zdravstvene troškove zemlje i preusmjerava resurse koji bi se mogli koristiti u rješavanju drugih zdravstvenih izazova ili razvojnih prioriteta. Smrti povezane s duhanom nisu samo preventivne tragedije, već imaju važan ekonomski trošak. Širom svijeta, ukupna ekonomska šteta od pušenja procijenjena je na više od 1,4 bilijuna \$ god-1, što je ekvivalent 1,8 \% svjetskog godišnjeg bruto domaćeg proizvoda (Goodchild i sur., 2018).

\section{Zakonsko uređenje}

Duhan je Zakonom o duhanu (NN, 32/19) definiran kao list kultivirane biljne vrste lat. Nicotiana tabacum L. i to u svim oblicima i stupnjevima uzgoja, obrade i pakiranja koji ne služe krajnjoj potrošnji. Duhanski proizvodi u smislu Zakona o duhanu jesu cigarete, cigare, cigarilosi, duhan za lulu, duhan za pušenje, duhan za šmrkanje, duhan za žvakanje i drugi duhanski proizvodi. Obiteljsko poljoprivredno gospodarstvo može proizvoditi duhan u listu samo na temelju pisanog ugovora o proizvodnji duhana s pravnom osobom koja je registrirana za obradu duhana - obrađivač duhana. Obrađivač duhana, proizvođači duhanskih proizvoda i uvoznici duhana i duhanskih proizvoda obvezatni su voditi evidencije o proizvodnji, prometu, utrošku duhana, uvozu, izvozu i zalihama duhana i duhanskih proizvoda. Navedene evidencije obvezatni su čuvati 5 godina (NN, 32/19). Kao članica EU, RH je bila obvezna prihvatiti i provoditi Protokol o uklanjaju nezakonite trgovine duhanskim proizvodima (2016) koji se veže uz Okvirnu konvenciju WHO o nadzoru nad duhanom (NN, 3/08). Navedeni Protokol predviđa donošenje mjera koje će spriječiti nezakonitu trgovinu duhanskim proizvodima te doprinosi međunarodnim naporima za uklanjanje svih oblika nezakonite trgovine duhanskim proizvodima i važan je za nadzor nad duhanom. Njime se navodi licenciranje proizvođača kao kontrolni sustav u proizvodnji duhana i duhanskih proizvoda. Duhan za pušenje definiran je Zakonom o trošarinama (NN, 1/19), a radi se o duhanu koji je rezan ili na drugi način usitnjen, svinut ili prešan u blokove i prikladan za pušenje bez daljnje industrijske obrade. Detaljnija razrada trošarine 
na duhan provedena je Uredbom o visini trošarine na cigarete, sitno rezani duhan za savijanje cigareta i ostali duhan za pušenje (NN, 106/18). Problem ilegalne prodaje, krijumčarenja duhanskih proizvoda, a i porezne utaje koji muči zemlje EU postoji i u Hrvatskoj, čime se gubi velik dio proračunskih prihoda. U Hrvatskoj 7,6 \% pušača opskrbljuje se na sivom tržištu, a dohodak ostvaren od krijumčarenja duhana procjenjuje se u Hrvatskoj na 32 milijuna $€$ god-1. Ujedno, na godišnjoj razini izgubljeni porezni prihodi dosežu 120 milijuna $€$, pri čemu se čak polovina prihoda gubi uslijed prekogranične kupnje duhanskih proizvoda zbog značajno niže cijene duhanskih proizvoda u Srbiji te Bosni i Hercegovini. Slična je situacija i u Sloveniji, susjednoj članici EU. U deset godina izravni gubici od ukupnih poreza na duhan koji nisu naplaćeni zbog krijumčarenja duhana iznose $2 \%$ bruto domaćeg proizvoda u RH. Rezani duhan sa sivog tržišta zamjenski je proizvod za cigarete koje se legalno prodaju, posebno u RH gdje rezani duhan čini 89 \% sivog tržišta. Ilustracije radi, u Sloveniji cijena deset kutija jednog brenda (šteka) cigareta iznosi $40 €$, u Hrvatskoj $36 €$, dok je u Srbiji te Bosni i Hercegovini cijena $26 €$. Nije stoga neočekivano da je praksa prekogranične kupnje cigareta najraširenija upravo u Sloveniji i Hrvatskoj. Razlog za ovako velike razlike u cijenama cigareta su u visini trošarina na iste te drugih poreza među zemljama. Istovremeno, razlika u cijeni legalnih cigareta i ilegalnih duhanskih proizvoda unutar jednog tržišta još je veća: cigarete napravljene iz ilegalno kupljenoga rezanog duhana deset su puta jeftinije od iste količine tvornički proizvedenih cigareta koje se regularno prodaju u Hrvatskoj (Privredni).

\section{Zaključak}

Duhan je kroz povijest bio obožavan kao,,sveta biljka“, ali i omražen. Nekad korišten u medicinske svrhe, danas je vrlo često krivac za razne bolesti, poput glavnog uzročnika raka. Mnoge su zemlje uvidjele profit u duhanu te su krenule sa širenjem uzgoja, a među tim zemljama bila je i Hrvatska koja je bila vrlo uspješna u uzgoju i proizvodnji duhana i duhanskih proizvoda. Tendencija većeg priroda duhana u Republici Hrvatskoj je nešto što se događa u posljednjih pet godina, nauštrb manjih površina za uzgoj i proizvodnju. Veći se prirod može zahvaliti obiteljskim gospodarstvima koji navodnjavaju svoje površine. Trenutno je Republika Hrvatska sa manje od 4.000 ha površine uzgoja duhana iz 2018. godine ipak među vodećim zemljama Europske unije. Na globalnoj razini to je neznatno, jer Kina, Indija, Brazil i Indonezija prednjače u uzgoju sa 60 \% svih svjetskih površina. Europska unija, čija je Republika Hrvatska članica, već 20 godina ne daje dovoljne poticaje za sadnju, stoga i ne čudi manjak površina za uzgoj duhana. Visoka cijena cigareta dovodi do premreženosti crnog tržišta, zbog čega trpi ekonomija Republike Hrvatske. Treba raditi na suzbijanju crnog tržišta, no nemoguće je predvidjeti njegovo iskorjenjivanje. Unatoč tome, oni koji se bave uzgojem duhana u Republici Hrvatskoj nastavljaju stoljetnu tradiciju u susret novim izazovima vremenu koje je ispred nas.

\section{Literatura}

Agroklub. URL: https://www.agroklub.com/ratarstvo/udruga-krupan-list-pitanje-je-ostati-ili-odustati-od-proizvodnje-duhana/53721/ (18.3.2020.)

Bauk, M. (2015) Povijest duhana. Diplomski rad. Zagreb: Sveučilište u Zagrebu.

Blecher, E., Ross, H., Stoklosa, M. (2014) Lessons learned from cigarette tax harmonisation in the European Union. Tobacco Control, 23 (e1), e12-e14. doi:10.1136/tobaccocontrol-2012-050728

Bouw, A. (2017) Tobacco taxation in the European Union: an overview. European Commission, Brussels, World Bank Group. URL: http://documents.worldbank.org/curated/en/493581492415549898/Tobacco-taxation-in-the-EuropeanUnion-an-overview (29.03.2020.)

Burns, E. (2007) The smoke of the Gods: A Social History of Tobacco. Temple University Press, Philadelphia.

Chaloupka, F. J., Straif, K., Leon, M. E. (2011) Effectiveness of tax and price policies in tobacco control. Tobacco Control, 20 (3), 235-238. doi.org/10.1136/tc.2010.039982

Čagalj, M., Gugić, J., Strikić, F. (2017) Povijesni pregled uzgoja duhana u Dalmaciji. U: Beljo, J. (ur.) Zbornik radova s međunarodno znanstveno-stručnog skupa,,Duhan u Bosni i Hercegovini-jučer danas i sutra“,48-59.

Čavlek, M., Gršić, K. (2008) Effect of topping height, ripeness at harvest and cultivar on certain properties of leaves 
from the upper stalk position of flue-cured tobacco in Croatia. Cereal Research Communications, 36 (3) - Suppl. 5, 1664-1667.

Doll, R., Peto, R., Boreham, J., Sutherland, I. (2004) Mortality in relation to smoking: 50 years' observations on male British doctors. British Journal of Cancer, 92 (3), 426-429. doi: 10.1038/sj.bjc.6602359

Dundović, D. (2019) Duhan u Republici Hrvatskoj i Bosni i Hercegovini kroz povijest uzgoja i krijumčarenja. Policija i sigurnost, 28 (4), 517-541.

Europska Komisija. URL: https://ec.europa.eu/info/food-farming-fisheries/plants-and-plant-products/plant-products/tobacco_en (18.3.2020.)

Europska Komisija (2010). URL: https://eur-lex.europa.eu/LexUriServ/LexUriServ.do?uri=OJ:L:2010:050:0001:0007

:EN:PDF (18.3.2020.)

Europska Komisija (2018). URL: https://ec.europa.eu/taxation_customs/business/excise-duties-alcohol-tobaccoenergy/excise-duties-tobacco_en (18.3.2020.)

Faostat (2018). URL: http://www.fao.org/faostat/en/\#data/QC(29.03.2020.)

Gallus, S., Schiaffino, A., La Vecchia, C., Townsend, J., Fernandez, E. (2006) Price and cigarette consumption in Europe. Tobacco Control, 15 (2), 114-119. doi: 10.1136/tc.2005.012468

Gallus, S., Lugo, A., Colombo, P., Pacifici, R., La Vecchia, C. (2013) Smoking prevalence in Italy 2011 and 2012 , with a focus on hand-rolled cigarettes. Preventive Medicine, 56 (5), 314-318. doi: 10.1016/j.ypmed.2013.02.009

Gately, I. (2001) Tobacco: A Cultural History of how an Exotic Plant Seduced Civilization, London, Simon \& Schuster. Godišnje izvješće o stanju poljoprivrede u 2018. godini. Ministarstvo poljoprivrede, Tkalec, N. (ur.), Zagreb, 2019. URL: https://poljoprivreda.gov.hr/UserDocslmages/dokumenti/poljoprivredna_politika/zeleno_izvjesce/2019_11_13_Zeleno\%20izvjesce2018.pdf) (18.3.2020.)

Goō̇chīd, $\bar{M}$., Nargis, N., Tursan d'Espaignet, E. (2018) Global economic cost of smoking-attributable diseases.

Tobacco Control, 27, 58-64. doi.org/10.1136/tobaccocontrol-2016-053305

Goodman, J. (1993) Tobacco in History, The Cultures od Dependence. London and New York, Routledge.

Goodman, J. (2005) Tobacco in History and Culture : an Encyclopedia. Detroit, Thompson Gale.

IARC Handbooks of cancer prevention, 2011. Tobacco Control. Volume 14. Effectiveness of Tax and Price Policies

for Tobacco Control. URL: https://publications.iarc.fr/Book-And-Report-Series/larc-Handbooks-Of-Cancer-Prevention/ Effectiveness-Of-Tax-And-Price-Policies-For-Tobacco-Control-2011 (18.3.2020.)

Jha, P., Marquez, P. V., Dutta, S. (2017) Tripling Tobacco Taxes: Key for Achieving the UN Sustainable Development Goals by 2030 . URL: https://blogs.worldbank.org/health/tripling-tobacco-taxes-key-achieving-un-sustainable-development-goals-2030 (18.3.2020.)

Kay, R. D., Edwards, W. M., Duffy, P. A. (2012) Farm Management, 7th edition. New York, McGraw-Hill Education.

Kourakos, M., Saridi, M., Kafkia, T., Rekleiti, M., Souliotis, K., Brokalaki, H. Koukia, E. (2017) Factors affecting mental patients' behaviors and attitudes regarding smoking. Asian Pacific journal of cancer prevention, 18 (7), 1991-1997. doi: 10.22034/APJCP.2017.18.7.1991

López-Nicolás, A., Stoklosa, M. (2019) Tax harmonization and tobacco products prices in the European Union, 2004-2015. Tobacco Control, 28 (4), 434-439. doi.org/10.1136/tobaccocontrol-2018-054342

Ministarstvo poljoprivrede. URL: https://poljoprivreda.gov.hr/duhan-i-konoplja/198 (18.3.2020.)

Okvirna konvencija Svjetske zdravstvene organizacije o nadzoru nad duhanom (NN, 3/08)

PC-Axix baze podataka. Državni zavod za statistiku (2018). URL: https://www.dzs.hr/ (18.3.2020.)

Privredni. URL: https://privredni.hr/gotovo-8-posto-pusaca-u-hrvatskoj-cigarete-nabavlja-na-crno (18.3.2020.)

Protokol o uklanjaju nezakonite trgovine duhanskim proizvodima (2016). URL: https://eur-lex.europa.eu/legalcontent/HR/TXT/PDF/?uri=CELEX:22016A1001(01)\&from=EN (18.3.2020.)

Spanopoulos, D., Ratschen, E., McNeill, A., Britton, J. (2012) Retail price and point of sale display of tobacco in the UK: a descriptive study of small retailers. PLOS ONE, 7 (1), e29871. doi.org/10.1371/journal.pone.0029871

Special Eurobarometer 458. Attitudes of Europeans towards tobacco and electronic cigarettes. European Union, 2017. URL: https://publications.europa.eu/en/publication-detail/-/publication/2f01a3d1-0af2-11e8-966a-01aa75ed71a1/language-en (18.3.2020.)

Stipetić, V. (2005) Razvitak poljoprivredne proizvodnje u Hrvatskoj: tendencije, stanje i osnovni problemi. Zbornik radova Ekonomskog fakulteta u Rijeci, 23 (1), 25-50.

Taylor, Z. G., Fisher, L. R., Smith, W. D., Edmisten, K. L. Wels, R., Jordan, D. L., Blankenship, S. M. (2011) The effects of 1-methylcyclopropene on ripening delay and holding ability in flue-cured tobacco. Tobacco Science, 48, 15-19. doi. org/10.3381/10-006.1

Thun, M., Peto, R., Boreham, J., Lopez, A. D. (2012) Stages of the cigarette epidemic on entering its second century, Tobacco Control, 21 (2), 96-101. doi: 10.1136/tobaccocontrol-2011-050294

Uredba EU 1307/2013. URL: https://eur-lex.europa.eu/legal-content/HR/TXT/PDF/?uri=CELEX:32013R1307\&from $=H R(29.03 .2020$.)

Uredba Komisije (EU) 1407/2013. URL: https://eur-lex.europa.eu/LexUriServ/LexUriServ.do?uri=OJ:L:2013:352:00 01:0008:HR:PDF (29.03.2020.)

Uredba Komisije (EU) 1408/2013. URL: https://eur-lex.europa.eu/legal-content/HR/TXT/PDF/?uri=CELEX:32013R1 408\&from=SV (29.03.2020.)

Uredba o visini trošarine na cigarete, sitno rezani duhan za savijanje cigareta i ostali duhan za pušenje (NN, 106/18) Vijeće Europske unije (2011). URL: https://eur-lex.europa.eu/LexUriServ/LexUriServ.do?uri=OJ:L:2011:176:0024:0 036:EN:PDF (18.3.2020.)

Vrzan, T. (2017) Uporaba duhana i čokolade kroz povijest. Diplomski rad. Zagreb: Sveučilište u Zagrebu.

World Health Organization (2014). URL: http://www.euro.who.int/ data/assets/pdf_file/0007/250738/140379_ Fact-sheet-Tobacco-Taxation-Eng-ver2.pdf (18.3.2020.)

WorldHealthOrganization(2017).URL:https://apps.who.int/iris/bitstream/handle/10665/255874/9789241512824eng.pdf?sequence=1 (18.3.2020.) 
Yeh, C. Y., Schafferer, C., Lee, J. M., Ho, L. M., Hsieh, C. J. (2017) The effects of a rise in cigarette price on cigarette consumption, tobacco taxation revenues, and of smoking-related deaths in $28 \mathrm{EU}$ countries - applying threshold regression modelling. BioMedCentral Public Health, 17 (676), 1-9. doi: 10.1186/s12889-017-4685-x

Zakon o duhanu (NN, 32/19)

Zakon o poljoprivredi (NN, 30/15)

Zakon o trošarinama (NN, 1/19)

Prispjelo/Received: 19.3.2020.

Prihvaćeno/Accepted: 1.4.2020.

Review paper

\section{Tobacco production in the Republic of Croatia}

\section{Abstract}

Tobacco has been attributed to many properties, from being a "sacred plant" to being not good for consumption. Nonetheless, tobacco has a tradition of cultivation as the New World was discovered. Usually, tobacco production is linked to the economies of the states. The Republic of Croatia also has a centuries-old tradition of growing tobacco. However, due to the weakly subsidization of tobacco production, production is stagnant, i.e. it is in a slight decline while the yield grows.

Keywords: tobacco, world, EU, tobacco law, Republic of Croatia
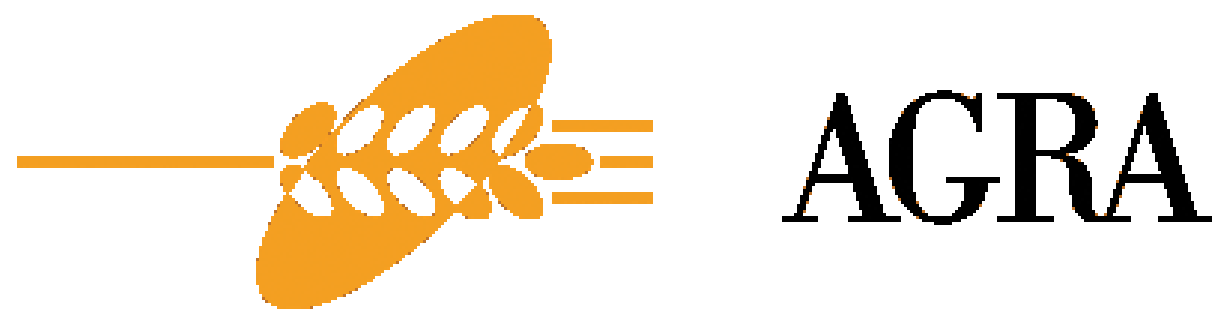

\section{INTERNATIONAL FAIR OF AGRICULTURE AND FOOD 22-27 August 2020 Gornja Radgona}

